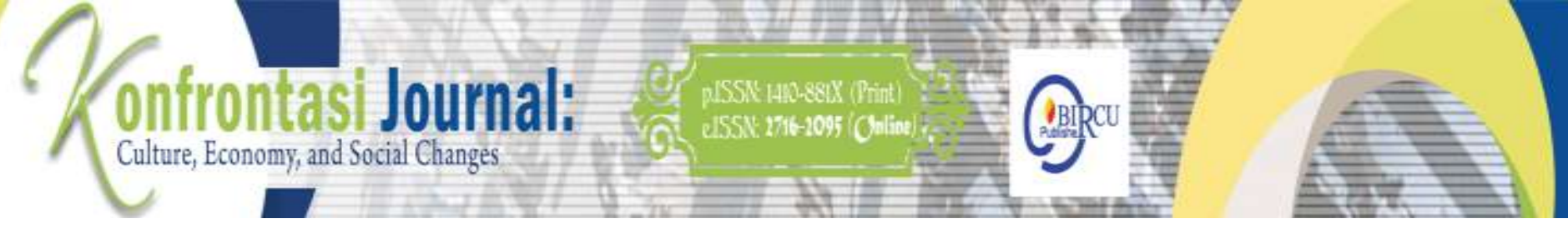

\title{
Political Islam, European Muslim and Terrorism Issues: A Reflection
}

\author{
Herdi Sahrasad ${ }^{1}$, Ibnu Rusyd ${ }^{2}$ \\ ${ }^{1,2}$ University of Paramadina, Indonesia
}

\begin{abstract}
In the period 2014-2015, the European Union was shaken by the influx of migrants from the Middle East, North Africa, and the Balkans (Eastern Europe) who increasingly flooded the western region of the white continent. In a March 2015 report, UNHCR said the conflicts in Iraq and Syria brought the number of asylum seekers in Western countries in 2014 to the highest level in 22 years. There were an estimated 866,000 asylum seekers in 2014. That number is a 45 percent increase compared to 2013. And, during the 2014-16 refugee crisis from the Middle East and Africa, millions of refugee flows from the Middle East and Africa were rejected. In this regard, Olivier Roy sees that in Europe itself there is a danger of radical Islamism, a Muslim terrorism movement that undermines European peace and undermines Western trust on Muslim communities and political Islam. This paper explains Roy's perspective and Islamic radicalism in Europe which does not benefit the position and image of Muslims in Europe and the West in general.
\end{abstract}

Keywords

Muslim; Islamism;

Europe; west; terrorism

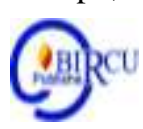

\section{Introduction}

The world is full of mysterious things, many Muslims are running to fatwas in search of the final answer to all their confusion. Few are willing to be patient to solve the mystery. Against the mysteries of a world full of injustice, corruption, and war, Islamists (those who believe in Islam as the solution to all problems) choose to create instant and straightforward answers. All the problems that exist, the solution is Islam. If there are problems in politics and economy in your country, then an Islamic state, Islamic politics, and Islamic economy are the cure.

Long story short, based on sociological analysis, Roy tries to explain the characteristics of Islamists, the reasons for their emergence, and the reasons for their failure to fulfill the demands of his agenda.

There are always moral messages in important books. The Koran, for example. For us, the Quran contains philosophical reflections on nature and society, so that its readers can behave morally in a just, polite, and humble manner. Roy's book also contains the same thing to a lesser extent. The main moral message in this book is Roy's call for the world, us, to be fairer to Islamists.

Islam is a religion of Da'wah means religion which always encourages its followers to always actively carry out Da'wah activities (Batubara, 2019). Since the 9/11/2001 WTC Bombing, the image of Islamism in the West has experienced a sharp decline: Muslims are considered a global terrorism group that threatens the safety and security of the world. Even as if Muslims are synonymous with terrorists. Islamism is cornered as synonymous with terrorism. Islam as a religion is even denounced by some non-Muslims as a religion of violence. Indeed, Islam faces extraordinary difficulties, dilemmas and cornered in its association in Western society. Islamophobia is spreading (Veldhuis and Beker, 2009). 
Konfrontasi Journal: Culture, Economy and Social Changes, 8 (3) September 2021, 152-162

ISSN: 1410-881X (Print), 2716-2095 (Online)

Herdi Sahrasad, Ibnu Rusyd: Political Islam, European Muslim and Terrorism Issues: A Reflection

DOI: https://doi.org/10.33258/konfrontasi2.v8i3.153

http://www.konfrontasi.net/index.php/konfrontasi2

\section{Literature Review}

Dikmejian (2014) stated that Today, in the Western/European tradition, the terms religious extremism (Islam), fundamentalism or Islamic radicalism, are often interchanged with each other, but the meaning is actually the same. The term "Islamic extremism" was coined by Gilles Kepel, "Radical Islam" by Emmanuel Sivan, and there is also the term "Islamic revivalism" by Esposito, or "Islamism" by Olivier Roy.

The terms with the pattern of "Islamism" are used to indicate the symptoms of "Islamic revival" followed by militancy and fanaticism which are often very extreme. Compared to other terms, "radical Islam", which is most often equated with "fundamentalist Islam".

The radicalism or fundamentalism movement in contemporary Islam is more often influenced by Islam's response to the West. There are at least two major issues that concern this Muslim group. First, they reject the secularism of Western society which separates religion and politics, churches, and mosques from the State. The success of the West in carrying out secularization is considered as something dangerous, because it can threaten Islam as a religion that not only deals with the afterlife, but also the world. Second, many Muslims want their society to be ruled in accordance with the Qur'an and Islamic law as state rules (Amstrong, 2001).

Esposito, an expert on Islam, elaborates on the term "fundamentalism" by associating it with three things as follows: First, it is said to be fundamentalist, if they call for a return to basic religious teachings or pure religious foundations; Second, the understanding and perception of fundamentalism is strongly influenced by the American Protestant group, namely a 20th century Protestant movement that emphasizes the literal interpretation of the Bible which is fundamental to the life of the Christian religion; Third, the terms fundamentalism and anti-American. Esposito, then argues that the term fundamentalism is very politically charged with Christian and Western stereotypes, and indicates a monolithic threat that does not exist. Therefore, Esposito does not agree with the West regarding the term "Islamic fundamentalism", he prefers to use the term "Islamic revivalism" or "Islamic activism" which according to him is impartial and has roots in Islamic tradition (Esposito, 1992).

\section{Results and Discussion}

In May 2016, Roberto Fico, Prime Minister of Slovakia, Central Europe, stated, "There is no place for Islam in Europe". Fico's statement in the media has sparked tremendous anger in the European Union. And PM Fico's statement is considered by the European Union to be outrageous and does not reflect the figure of a leader who protects all communities. Europe during 2014-2016 struggled to deal with a very heavy refugee (Muslim) crisis from the Middle East. Have efforts to stem the tide of Middle Eastern and African refugees succeeded in bringing about a significant reduction in the number of immigrants to Europe? (Germany And Refugees, 2016).

The answer turned out to be no. And what is clear: Germany under the leadership of Prime Minister Angela Merkel in 2016 has taken on this humanitarian mission and the burden of immigrants in Europe, and took on this gigantic task shift with full responsibility. Germany is an example to the Islamic World, East and West in rescuing about 1 million refugees, an extraordinary humanitarian vision and mission. A successful 
integration of refugees can even determine and decide on the political stability of Germany, the largest country in the center of Europe.

In fact, during 2014-2016, Europe was reeling from the influx of migrants from the Middle East, North Africa and the Balkans (Eastern Europe) that were increasingly flooding the western region of the white continent. In a March 2015 report, UNHCR said the conflicts in Iraq and Syria brought the number of asylum seekers in Western countries in 2014 to the highest level in 22 years. It is estimated that there were 866,000 asylum seekers in 2014. That number increased by 45 percent compared to 2013. And, during the refugee crisis from the Middle East and Africa 2014-2016, millions of refugee flows from the Middle East and Africa were rejected, blocked and made it difficult to enter Eastern Europe that many of its citizens also migrated to England, Germany, Switzerland and other parts of Western Europe. International pressure was finally able to force Eastern European countries to open their borders to the flow of refugees, who were then largely accepted by Germany.

In the 2014 Asylum Trends report, it was stated that around 3.9 million refugees from Syria were accepted in Lebanon, Turkey and Jordan. Syria supplied nearly 150,000 asylum requests in 44 industrialized countries last year. Iraq takes second place with 68,700 submissions

In recent years, the conversation of the world community has focused on the flow of Muslim immigrants to Europe - most of whom are refugees from the Syrian conflict - who fled the raging war in their country to the promising lands in the European region. It's no longer a small number, their number is hundreds of thousands. Refugees victims of this war did various ways, including sailing across the Mediterranean Sea in small boats full of human lives, to walking on rails from Hungary and Greece to Germany.

In Europe, there are many communities with Muslim characters, whether they are Arab, Turkish, Moroccan, Algerian, Albanian, Bosnian or Pakistani and Iranian. However, they speak different languages, have different cultural backgrounds and religious traditions. Academic Kerem ktem of the University of Oxford stressed that it was neither possible nor necessary to establish a unified form of Islam for all of Europe, as there was too much diversity to consider. Unfortunately, the diversity of Muslims is not noticed by European citizens, and they focus more on Islamization which they perceive as a "threat or danger".

In recent years the anti-Islamization movement has bubbled across the European Union. They feel anxious, disappointed, worried and trembling, even mixed, seeing the growth of Islam among European society. Islam in Europe is growing very rapidly. No less now the population of Europe, nearly 40 million. The largest in France and Germany. Meanwhile in England, Melanie Phillips, the journalist who coined the nickname Londonistan, describes how big the influence of Islam on the British capital is today. From 2001 to 2016, 423 new mosques were built in London, while about 500 churches have been closed. The Hyatt United Chuch was bought by Muslims from Egypt and turned into a mosque. Similarly, the church of St. Peter was converted into the mosque of Madina. The Brick Lane Mosque was originally a Methodist church. It's not just the buildings that have changed because in 2016 the number of converts in Londonistan has doubled (Suprana, 2017).

The issue of the Islamization of Europe began to blow when many surveys said the number of Muslims was growing significantly on the continent. More than 20 million Muslims live in the $28 \mathrm{EU}$ countries. Their population in Europe grew from four percent in 1990 to six percent in 2010, according to the Pew Research Center. By 2030, Muslims are projected to make up eight percent of the continent's population. 
Around 4.7 million Muslims live in Germany and an almost equal number live in France, making these two countries the most adherents of Islam in the European Union. In France, the number of Muslims reaches 7.5 percent. That figure is expected to rise to more than 10 percent by 2030 . Muslims make up 5.8 percent of the population in Germany, 4.8 percent in the UK and 3.7 percent in Italy. By comparison, Muslims in the United States make up only one percent of the population.

As a result of all that, the people in the European Union are threatened by the large number of people who convert to Islam, and even become the pioneers of Islamic revival in Europe. Since Geerd Wilders from the Netherlands, who stirred up anti-Islam and immigrants, now there are growing right-wing groups that are anti-Islam and immigrants throughout the European Union. On the one hand, Islamophobia is sweeping Europe. Islamophobia or Islamophobia refers to the notion of excessive fear or worry about the religion of Islam and Muslims.

On the other hand, media reports assert that, the power of Christianity in Europe is waning, perhaps on the verge of extinction, because Christianity, for the most part, seems unacceptable to the common sense of European society. Islam itself is not easy to enter Europe. In fact, Islam in Europe faces difficult problems and challenges, including:

First, Europe is still looking for Islam whose principles are in line with modern culture and European values. Islam is considered not yet acculturated with European society and is considered the others. Although immigrants from Muslim countries have been coming to Europe for decades, Muslims on this continent seem to live "alone" and exclusive, culturally hardly attracting the attention of the wider community to interact.

Second, there is skepticism that Islam is incompatible with European values. Islam is considered a religion that does not uphold democracy. Therefore, Islamization was opposed by Europeans.

Third, in the perception of European citizens, Islamic law is the biggest danger to democracy and human rights in the 21 st century. And Muslims are accused of being the drivers of Islamization of radicals who encourage acts of terrorism in Europe to become more massive among Muslim youths.

Islam, both orthodox and radical, is perceived by Europeans as the source of human sufferings and pains. As a result, demonstrations against the Islamization of Europe took place on February 6, 2016 in 14 European countries. Actions organized by various Islamophobic groups such as Pegida (Patriotische Europer gegen die Islamisierung des Abendlandes/Patriotic Europeans Against the Islamization of the West) Germany and Block Against Islam-Czech were held in several countries including the Netherlands, France, Czech Republic, Estonia, Finland, Germany, Poland, Slovakia and Switzerland.

Europeans are determined to fight against Islamization which they think continues to be massive in Europe and they are disgusted by the rapid flow of Muslim migration from conflict countries in the Middle East and view European policies towards migrants as stupid and suicidal. Sex attacks and robberies against women in Cologne (Cologne), Germany on New Year's Eve 2016 where young men from Arab countries were accused of being the perpetrators of the attacks, became one of the triggers.

Analysts ask: Did the incident in Cologne trigger mass anti-Islam and Muslim movements in many European countries? What do Europeans understand about Islam that they are so anxious and afraid? In this connection, Michael Ley helps us to read the prejudices, suspicions and fears that haunt European citizens. Ley firmly stated that Islam, both orthodox and radical, is the source of human suffering/wounds/grief. Michael Ley suffers from Islamophobia, and it is not surprising that he mentions that Islamic sharia is the greatest danger to democracy and human rights in the 21 st century. 
However, a Muslim will be confused to choose between maintaining their original identity or having to assimilate into European culture where they are forced to lose their religious and cultural norms which they brought from their home country. For Tariq, this is an act of state intervention in individual territories. So, the offer he made was that the state should give space to Muslims in Europe to become citizens and be treated equally, so the term European Muslims were not Muslim in Europe.

Across Europe, the increasing number of disputes between Muslims and the European social sphere, increasingly led many to question the compatibility of European and Islamic ideals. Britain, for example - where Tariq Ramadan lives and works - has been locked in a heated debate for weeks about whether Muslim women should be allowed by the government to wear the veil/hijab or not.

In this regard, challenging powerful figures such as Osama bin Laden and other radical Islamists, who seek to pit Muslims against the West, Tariq Ramadan seeks to focus on encouraging European Muslims to remain true to their faith and loyal to the secular society in which they live. It was an urgent task, he said.

At the beginning of the 21st century, Tariq Ramadhan argues, the 15-20 million Muslim population in Europe - most of whom are already European citizens - can no longer see themselves as foreigners in their new homeland. Instead, said Ramadan, they will see Europe as a "house of testimony" where Muslims bear witness to their religious message by living peacefully in the modern world.

To do so, says Tariq Ramadan, Muslims must return to their Islamic roots, but with a completely different goal compared to the literalist Salafists who seek to recreate the "purity" of early Islam. The goal is "to return to the roots of tradition, find its universality so that it can be adapted to today's conditions and needs. Reform of Islamic ethics is not a compromise with the current situation, but a step to answer current challenges with an adaptive and transformative approach so that Muslims are able to thrive in the midst of modernity." , not old and not stagnant or alienated from modernism," he said. In Tariq Ramadhan's view, this approach is not only an option, but a necessity. The social and cultural norms of 8th-century Arab tribes - some of which have been tightly woven into Islamic practice for centuries - are clearly irrelevant to European Muslims today.

In this regard, the author agrees with the perspective of Prof. Tariq Ramadan, a Muslim intellectual who is known through his cultural motto "Muslim Europe, not Muslims in Europe", where he tries to promote equality between Muslims (immigrants) in Europe and native Europeans through integration. between people, between people.

For him, it is not enough for Muslims to be granted a residence permit in Europe, but they must also have the same political, economic and social rights. This thought may be a reflection of Tariq's experience as an Egyptian immigrant who was born and lived in Switzerland since 1962.

Tariq sued the stereotype of the Arab nation - Muslim - which is always viewed negatively by the West. This perspective leads to the conclusion that without Islam problems will be reduced in the West and this is clearly wrong.

"There is no other way than rereading, reunderstanding, being self-critical," said Tariq. That the Koran is the word of God, as it was revealed to Muhammad. But this means seeing the Koran as "an eternal message met with historical reality." In this case, the dogmatic approach to the text has nothing to do with the text, "but with the mind of the reader," he said.

In my opinion, Tariq is not a double-speaking intellectual but he uses different languages according to the scientific capacity of his audience but still conveys the same meaning. On the other hand, he confirmed that he was a controversial intellectual. That is, 
his thoughts will bring praise and criticism. But for him to be a controversial person is a good thing because it makes other people think and write to refute his thoughts.

As a Muslim reformer in Europe, there are three stages of approach that he uses to develop his ideas: First, he refers to the main sources, quotes the Qur'an and the Hadith of the Prophet Muhammad and understands the textual meaning of the text.

Second, he explained the ulama's interpretation of the Al-Quran and Hadith and saw the possibility of other interpretations that did not change the message of the text.

Third, he tries to write down his reformist understanding, which is an understanding that can be implemented in today's life. For Tariq, being a reformer means presenting a different perspective.

Of course, Tariq Ramadan's views raise pros and cons in Europe, however, his tireless efforts to integrate Islam in Europe should be appreciated and researched by Islamic intellectuals, scholars and academics as a comparative study that deserves attention.

\subsection{Why and How Islamism Emerged}

In terms of Islamism and the dynamics of Muslims in Europe, Olivier Roy's view of Islamism at the global level is interesting. Roy reminds readers of his book that there is a 'curtain of illusion' (my own expression) that must be removed first, before we go any further in judging Islamists. The curtain is the perception that Islamism is a chain that goes back to the Islamic Middle Ages; the perception that Islamists want to turn the wheel of history; the perception that the politicians of religion are only Islamists (Roy, 1992).

Perhaps Roy is a bit irritated by mass consumption in the West at the news of the Islamist movement which has intensified in the last two decades. The mainstream media often overdo the news about the "threat" of Islamism. As if Islam is the biggest threat to Western Civilization. It was clear that Roy disagreed with Samuel Huntington. However, Roy's intention to be fair in judging Islamism deserves appreciation. To me, it's just a matter of being backed up by the right scientific attitude.

As Roy admits, this book seeks to explore the reasons behind the failure of Islamism, even in his own countries such as Egypt, Turkey, Iraq, and Indonesia. After reading Roy a bit, I think their failure has a lot to do with their own immaturity. Roy targets this attitude, and calls it nostalgia and apologia (Roy, 1992).

Is it illegal to have this apologetic wishful thinking? I don't know, I'm not a mufti. However, the result is always nostalgic with the imagination - which is often not historical, but dogmatic - of the glorious past of Islam; and as a result of always claiming that Islam as a religion is complete and more advanced than any other civilization, eventually those who are infected with the Islamism virus become stagnant and uncritical in their thinking.

Without rational reasons, they are simply anti-advancement of other civilizations, especially Western civilization. This is something funny, in Roy's view. On the one hand, Islamists are the result of modern education which is secular and Western-centric; however, at the same time they despise the Western world who educated and raised them. Maybe, like someone who denounces capitalism but still has an iPhone or Samsung in his hands. As funny as Osama bin Laden, who cursed and bombed the United States, but stayed true to his dollar.

\subsection{In What Sociological Space Do They Appear?}

The introduction to this book is important for several reasons. First, through twentyseven pages, Roy wants his readers to understand that this movement has actually failed. That is, we don't have to think big of something that is not big at all. Megastar footballers 
like Messi, do not need to take it seriously if there is a village champion footballer who suddenly challenges him.

This is another way by Roy to remind the global world not to over-exploit the fear of the masses by preaching as if Islamism is a rival to democracy. Second, why this section is important, is that it explains the sociological underpinnings of the emergence of Islamists.

Let's follow Roy's explanation. Islamists are not an irrational traditionalist group. Their agenda is not to turn modernism into 'Medieval-ism'. They are far from it. If they glorify Islam's past, it's not because they really want to go back to it. Maybe they knew that was impossible. What they are after is public sympathy and seats of power (Roy, 1992).

The way they run their own agenda is quite modern; namely through propaganda, revolution, and if necessary terrorism. In medieval Islam, there was no propaganda, revolution, and terrorism. The methods used by modern defenders of Islamic law are the greatest innovations in Islam.

Still according to Roy, innocent people who follow the footsteps of the Islamists can also not be called traditional Muslims. Most of them live precisely with urban values. Consumerism, vertical social mobility, and their uprooted from traditions in villages, madrasas, and pesantren, are proofs that they are no longer traditionalists.

Is it helpful for you, right? Yes, this explanation is enough to help us to understand why, in Indonesia, for example, Islamists who follow the political party of the Ikhwanul Muslimin's biological son, namely PKS, then followers of Hizb ut-Tahrir, Jamaah Islamiyah, and the Masyumi Party are always concentrated in cities, not in villages; rooted in modern recitation groups, and not Islamic boarding school (pesantren).

After getting to know more about the sociological conditions and situations of the Islamism movement, in part two of this article, we move on to Roy's explanation of the basic differences between Islamic politics and modern politics. Why did Roy feel the need to do it? What can be read is, Roy wants us not to confuse politics according to Islam and politics according to the modern world. Roy sees a problem when we use the comparative method to dissect the political agendas of the Islamists.

The comparison allows us to compare Islamism-style politics with modern politics; which means we are trying to measure the 'truth' of Islamism by modern political standards. Obviously, this is unfair, to Roy. In Roy's own words, the method of comparison tends to make us take one of the parties being compared as the norm for judging the other, without actually making the "other" speak for itself. Roy wants us to let Islamism speak for itself.

\subsection{What is the Nature of Modern Politics?}

Roy seemed to show sympathy here. However, he still adheres to objectivism. Why did I say that? In this section, Roy is consistent so that we do not judge Islamism harshly and haphazardly, by first requiring us to objectively identify what are the characteristics of modern (Western) politics, and what are the characteristics of 'Islamic' politics.

That's right, this is a researcher's kindness. Even so, Roy's intention to be objective also led him to openly admit that the political ideals of Islam are nothing more than an unproductive endeavor, imaginative, full of nostalgia and apologia, like a dream in broad daylight.

Modern politics, it must be admitted, is the result of (religious) reforms in the West. In the political realm, the discovery of modernity lies in the emergence of an autonomous, independent, free political space, separated from the religious and private spheres, and manifested in a new law-based state. One of these modern political moments was the 
French Revolution, when power passed from the king and the church to the common people. The world also witnessed the birth of secularism.

Secularism in politics can be born as a result of the church's institutional decision to limit itself (or acknowledge the fact that it is indeed limited). Finally, modernity was increasingly sought after, imitated, and applied throughout Europe. It is as if there is an unspoken creed that says "there is no salvation outside of modernity". Roy sees, the modern political configuration is typical of the Western World. As for Islam, it has its own configuration.

Roy felt the need to emphasize this distinction. Even when asked to explain what the political configuration of Islam is, he again has to return to traditional Islamic texts that talk about politics. He also said that, even though Islamists are no longer traditionalists in their personality, when they need an Islamic basis for their activism, they will still refer to traditional texts as well.

Through this distinction, Roy wants to resolve a meaningless debate that has filled the mass media about the incompatibility of Islam with modern politics. Frankly, it's not compatible. In Islamist reference texts there is no such thing as a nation-state, people's representation, even civil liberties. However, that does not mean that there is no politics and justice in the history of Islam. The Islamic perception of freedom is almost certainly not the same as freedom in the eyes of the modern West. Islam always prioritizes justice, then freedom. We today, no. Freedom is justice itself.

\subsection{Islamists Have No Thoughts, They Only Have Imagination}

Roy did not see any Islamic political thought; things that make Islamism not fundamentally solid. Instead of thinking, what grows and thrives is imagination. Roy calls it the Islamic political imagination.

Sociologically, Roy asserts that to see an imaginary entity in the heads of the majority of Islamic political defenders, you should not look for it in the academic writings of Muslim scholars. If we go there, what we see is a rich thought - but the Muslims themselves have never paid attention to it. The fact is that it is. There are many journals and theses on Islamic political thought that intend to combine Islam with modernity. But what the defenders of Islamic politics practice is an imaginative and apologetic political model, not smart and advanced politics.

You only need to read political-religious literature (such as the works of Al-Mawardi and Al-Ghazali), Islamist literature (such as Hasan al-Banna, Mawdudi, and Sayyid Qutb), or listen to sermons in mosques (both Sunni and Shia)., to admit that there is an Islamic political imagination which is dominated by one paradigm which reads: "The ideal Islamic political community is the early believers, namely the Prophet and the first four caliphs, or the Prophet and his family."

According to Roy, it is true that the political experience of the Prophet Muhammad, which was then followed up solemnly by his four successors (according to the Sunnis), or by his verse experts (according to the Shia), has historical reality. That in itself is not entirely imaginary. What is imaginative is the image in the heads of militant political Islam that this very distant period is the most ideal model of politics and society. In Roy's words:

In their imagination, Islam was born as a religious sect as well as society, a religious and political community, where there is no special institution other than the Prophet as the narrator and translator of the transcendent divine law that governs all aspects of human life. 
An egalitarian society, which has no differentiation, placed under the auspices of a legislator who must be obeyed totally in the social, private, religious, political, and economic fields (Roy, 1992).

Even ordinary readers will find it easy to understand that this ideal picture is indeed strong enough to encourage Muslims to engage in practical politics. Roy also saw the same thing. What is different is that Roy places this idealization of the past as imagination (a psychological creation that arises from latent impulses such as humility in the face of modernity), and not as historical, rationalist, let alone empirical political thought.

According to Roy, this paradigm of Islamic political imagination has definitively become a symbol whenever Islam wants to be associated with politics - even though in reality this kind of nostalgia has never been successfully rebuilt. This paradigm is quite successful in trapping many people, including educated Muslims and orientalists. This trap allows them to immediately imagine the reign of the Prophet and the four caliphs (or imams), when they are asked about Islam and politics. Even Arab secular nationalists, when asked the same thing, always refer to the same imagination (Roy, 1992).

\subsection{Outdated Politics}

We see that the inability of the modern Muslim community to formulate a rational political theory is a prelude to the stagnation of their political thinking so far. Apparently, this is the basis of Roy's attitude to call it a mere imagination. It was only in Ibn Khaldun (1332-1406) that there was a glimmer of hope. Modern academics see Ibn Khaldun's distinction from other Islamic political promoters.

Ibn Khaldun himself always praised God's name, prayed to Him, and praised the Prophet in his magnum opus, Muqaddimah. But, that is the hallmark of his piety as a Muslim. Just that. When discussing about power, power, and wealth in the book, he is rational and never dogmatic. He speaks as a scientist, shows empirical reality, only then draws a general theory from him (Khaldun, 1986; Kuru, 2019).

While other scholars, departing from the assumption (or imagination) about Islam as the best religion and people, then idealize everything that has ever happened, especially in the early generation period, then arrange norms in governing the state. No theory, no thought. They do have consistent themes, but the paradigm from which they depart is still imagination. According to Roy:

From this paradigm, it will produce a number of recurring themes in the study of Islamic political thought. The themes are, the absence of separation of religious, legal, and political areas; and sharia which must be the only source of law and norms of behavior, both the behavior of rulers and ordinary people. There is no such thing as a political space that is autonomous from religion, which has its own rules, its own positive laws, and its own values. The state has never been known as a territorial state, the government is a global and international government of all the faithful (Roy, 1992). 


\section{Conclusion}

Islamism must be recognized as a fairly active response to modernity and changing conditions of global civilization but still leaves marginal space for Muslims. Islamism has always been intertwined in revolutionary ways. Iran today is the result of the revolution of the Islamist (Shi'a) groups there. Roy also acknowledged the success of Shia Islamists - in the end - in controlling a country. Recently the Taliban has also carried out a revolution in Afghanistan.

Islamists always have the opportunity to succeed in seizing power. The Taliban we just mentioned, is the freshest example. However, what we also want to see is what kind of politics they applied when they finally achieved power. Roy did not want to compare it to non-Islamist politics. Roy seemed uncomfortable with the comparison method.

What Roy wants to emphasize in this book is that there is no essential change of the political and economic rules of the game in Middle Eastern geostrategy, with the presence of these Islamists. Everywhere, even in countries that they have been able to control such as Iran, Pakistan, Afghanistan, and in some cases, Iraq, the oppressed still exist, ethnic and sectarian conflicts are still sharp, group competition for power is still hot, corruption is enriching rulers, restrictions on women's activities are considered a religious obligation, and restrictions on creativity are set to protect religion. In The Crisis of Islamic Civilization (2009), Ali Allawi said that the power that was finally taken by political Islam was the final proof for their own failure. They are powerful, but they are no better than their secular, authoritarian predecessors. For hundreds of years, the Middle East has always had a problem with authoritarianism.

\section{References}

Azyumardi Azra, Kaum Muslim Perlu Eropanisasi Islam di Eropa, Republika, Selasa , 07 June

Ayu Rahmadani, Migrasi dan Transnasionalisme: Sekuritisasi Imigran Muslim dan Kelompok Imigran Muslim Transnasional di Belanda, paper Hubungan Internasional, Fisip Unair, Surabaya, 2015.

Barry Buzan et.al, Security: A New Framework for Analysis, London: Lynne Rienner.,1988

Batubara, Maria Ulfa. (2019). Islamic Communication Pattern of Judges in Dealing Conflict of Muslim Families in the Religious Court Medan. Budapest International Research and Critics Institute (BIRCI-Journal).p.373-386

Biyanto, Teori Siklus Peradaban: Perspektif Ibnu Khaldun, Surabaya: LPAM.2004.

Germany And Refugees: The Perils Of Failed Integration 04/06/2016, http://www.huffingtonpost.com/markus-ziener/germany-and-refugees-theb_9618046.html diakses 5/5/17 pukul 23.00

Ibnu Khaldun dalam Kitab al-Ibar (Tarikh Ibnu Khaldun) Darul Qudus al-Ilmiyah, Beirut Lebanon,2004.

Jaya Suprana, Fenomena Londonistan Menuju Peradaban Abad 21 http://www.konfrontasi.com/node/109159 diakses 6/3/17, pukul 22.00.

John L. Esposito, The Islamic Threat: Myth or Reality (New York: Oxford University Press, 1992), pp.8-9.

Junaidi Abdullah, "Radikalisme Agama: Dekonstruksi Ayat Kekerasan dalam alQur'an”, dalam Jurnal Kalam, Vol. 8, No. 2, Desember 2014, p. 3 ADDIN, Vol. 10, No. 1, Februari 2016 
https://www.merdeka.com/khas/hantu-islamisasi-di-benak-eropa.html diakses 5/4/17 pukul 21.00

http://www.republika.co.id/berita/koran/teraju/15/01/27/nityg83-membendung-islam-dieropa

Karen Amstrong, Berperang Demi Tuhan: Fundamentalisme dalam Islam, Kristen dan Yahudi (Jakarta: Serambi, 2001).

Leonard Binder, Islamic Liberalism: a Critique of Development Ideologies (Chicago and London: The University of Chicago Pres, 1988

Moroccon Policy Working Paper 6, 2009.

Natasha T Duncan, dan Eren Tatari, Immigration and Muslim Immigrants: A Comparative Analysis of European States. European Journal of Economic and Political Studies, 2011.

Olivier Roy, The Failure of Political Islam, Cambridge: Harvard University Press, 1992.

R. Hrair Dikmejian, Islam in Revolution: Fundamentalism in Arab World (New York: Syracuse University Press, 1985), pp. 25- 36.

Soeren Kern,Macron Vows to Reform Islam in France"It is time to bring in a new generation.",https://www.gatestoneinstitute.org/11893/france-islam-reform

Tinka Veldhuis dan Edwin Bekker, Muslim in the Netherlands: Tension and Violent Conflict.

Unaesah Rahmah , Tariq Ramadan, Ilmuwan Muslim Pengusung Kesetaraan di Eropa https://islami.co/tariq-ramadan-ilmuwan-muslim-pengusung-kesetaraan-di-eropa/ 